\title{
COMMENT
}

DOI: $10.1057 /$ s41599-018-0088-6

\section{The interior as interiority}

Vlad lonescu ${ }^{1}$

\section{ABSTRACT}

The goal of the following article is two-fold: first, it aims to introduce some of the fundamental challenges concerning the theory of interior design, with the aspiration of stimulating further research on the topic, notably concerning the relationship of interior design to adaptive re-use, anthropology and the fine arts. Second, the text introduces a series of essays that complement this paper, which have been collected under the title Interiorities: Artistic, Conceptual and Historical Reassessments of the Interior. The collection proposes an interdisciplinary approach of the interior, both as an architectural challenge and as an opportunity to represent subjectivity in all its dimensions, as understanding, reflection, memory, imagination and affect.

\footnotetext{
${ }^{1}$ Faculty of Architecture and Arts, Hasselt University, Hasselt, Belgium. Correspondence and requests for materials should be addressed to V.I. (email: vlad.ionescu@uhasselt.be)
} 


\section{Introduction}

rchitectural history has long conceived the interior as a distinct aspect of architectural design. Various historical studies have documented how an interior's identity can evolve independently of the architectonic structure of a building (Hollis, 2009; Massey, 1997). Interiors constitute the most fragile feature of design because they are often temporary and secondary additions. They can be conceived simultaneously with the building but they are also easily transferrable and adaptable. Sometimes interior design emerges simultaneously with the exterior structure, like in the case of Art Nouveau. As Walter Benjamin argued, when the architect designs both the furniture and the structure, the interior loses its autonomy and becomes highly individualistic (Benjamin, 1999, p 9). Interior and structure follow one organic sense of form; they grow as if from one germ. However, this holistic conception of the Jugendstil signals an ambiguity about the architectural status of the interior: is it supposed to be conceived separately from the rest of a building? This ambiguity regarding the interior justifies the distinction between decorator and interior designer (Massey, 1997). A subtle gradation determines the relation between the two: if the decorator has less of an impact on a building's structural identity, this is because to decorate implies a different relation to the identity of a building. Adorning and integrating objects within its structure affects its spatial experience (but not yet its structure). Any intervention on this level is easily reversible and adaptable. Decorating and designing an interior space concern distinct levels of interventions, determining to different degree the extent to which architecture can change.

Nevertheless, the mere regulative distinction between decoration versus structure echoes another well-known dichotomy in modern thought, namely Kant's distinction between ornament (parerga, something secondary) and pure form as the authentic constituent of beauty (Kant, 2000, pp 110-111). In the foundational work of modern aesthetics, The Critique of the Power of Judgement (1790), interior design returns at key moments. Kant argued that decorations of all sorts (from wallpapers to mouldings and furnishings, rings and pill boxes) represent actual beauty because they are there without any use, "merely to be viewed, in order to entertain the imagination in free play with ideas and to occupy the power of aesthetic judgement without a determinate end" (Kant, 2000, p 201). Lack of a function guarantees a pure aesthetic experience. On the other hand, too much charm, external addenda and draperies, sensations and frames inhibit the pure aesthetic judgment (which concerns form, structure and outline). The history and theory of interior design has proved that this dichotomy between decorations and structures, between passing charms and pure forms, is more complex. Recent research has provided comprehensive historical overviews of interior design (Sparke, 2008; Pile and Gura, 2014; Raizman, 2003). Architectural theory approached the interior in a broader conceptual sense, combining a speculative philosophy and the phenomenology of dwelling-the "usual suspects" have been Gaston Bachelard, Martin Heidegger or Christian Norberg-Schultz-with the more prescriptive insights of modern architects. (Taylor and Preston, 2006; Lane, 2007; Weinthal, 2011).

\section{Interiors}

However, interior design is more than a spatial arrangement or a collection of objects. We argue that the interior is a moment when a building receives its cultural significance. It is through interior design that a tectonic structure "speaks" to its users, involves their gender differences and division of roles. Architecture enters cultural debates when it is arranged as an interiority, that is to say, as a place that distributes functions (work, rest, move, etc.) in a given community. Existing literature has pinpointed this intuition: the "political interior" is the moment went a design is integrated in a broader cultural debate about the division of space according to responsibilities, traditions and rights (Thompson and Blossom, 2015). Mark Pimplott's notion of the "public interior" also designates a cultural space that people continuously negotiate (Pimlott, 2016). Interior design and decoration are more than sartorial additions that cover an engineered structure; they are a necessary dimension that turn architectural space into a liveable place with a given stability, desirable order and readable cultural hierarchy (Verschaffel, 2002).

The fact that interiors can change explains their adjustable and transient nature; it also justifies adaptive re-use as an inherently critical function of interior design. Interiors are converted also because of an inherent qualitative difference, as Trachtenberg has convincingly shown, between the time of the building and the time of its lifeworld (Trachtenberg, 2010). Buildings tended to outlast, at least in the premodern world, the changes in the lifeworld. Historical time can involve faster changes than the time of a building. This interesting analysis raises even more pregnant questions regarding the interior, the most temporary dimension of any building. When buildings change "from inside out", the new interior always and already says something about the world that changes outside itself. The adapted building is as much of a palimpsest as a city's urban fabric (Machado, 1976; Corboz, 2001); yet the re-adaptable interior is a profoundly political palimpsest as it testifies to economic, religious or artistic changes (Hegewald and Subrata, 2012). When the profane takes over the sacred space faster than ever and when contractors determine the identity of the built environment, adaptive reuse can no longer just be a question of aesthetic taste and a vaguely felt mood. The adapted interior should represent these vehement changes in the way that communities chose to value their world.

This brings us to the idea that the interior has always been indistinguishable from people's inner life - let us call it their interiority. The writer's room is more than an enclosed space where someone writes but a carrier of specific types of imagination, that of a novelist or of a psychoanalyst (Fuss, 2004; Rosner, 2005; Bauer, 2016). As Virginia Wolf observed, the kitchen is the space where a social type emerges, namely the cook, a character that changes from the Georgian cook-"a creature of sunshine and fresh air; in and out of the drawing-room, now to borrow The Daily Herald, now to ask advice about a hat"-to the Victorian cook who "lived like a leviathan in the lower depths, formidable, silent, obscure and inscrutable" (Wolf, 1924, p 5). In other words, the interior is an intramural arrangement of any built environment that actualises a specific interiority. The interior is the condition of possibility that allows us to represent these (inter-) subjective dimensions: power relations, intimacy, (semi-) public encounters, imagination, memory, attention, desires and understanding. These dimensions define our symbolic representation, the ability that overcomes our biological adaptability and allows us to understand and represent the world through language. Domesticity is such a specifically human language, not just a spatial but also a symbolic arrangement of the interior as a home. The home is the house that contains a given symbolic order, stability and sense of time (Verschaffel, 2002; Rice, 2007; Smyth and Croft, 2006). The difference between a home and hotel apartment concerns less the interior design and the spatial arrangement as the inhabitant's temporal, emotional and imaginative relation to the interior. The home implies a strongly embodied relation between an interior and the sense of interiority that it brings about (memories, sense of time, directions, fantasies, etc.). 


\section{Interiority as a figure}

The thematic article collection that this article accompanies ${ }^{1}$ addresses this complex relation between interior design and interiority, between architectural structures and the subjectivity that they engender or challenge. The house (interior) as a home (interiority) is particularly revealing because the modern rationalist design emerges in debates concerning interior design. Already in the middle of the 19th century, Jakob von Falke (the first curator of the Viennese Museum of Applied Arts) referred to the Renaissance interior as rational and adaptable to modern life (Von Falke, 1866). The Renaissance interior was also the model for Georg Hirth as it harmonises structure and ornament (Hirth, 1886). The rational adaptability that modern life requires was related to interior design. Cornelius Gurlitt, besides famously revaluing Baroque architecture, also described the rules that the bourgeois house was supposed to follow (Gurlitt, 1888). Modern life, from the middle of the 19th century onwards, is centred around an interior that accommodates its fundamental values, that is, the rational spatial division, the employment of honest materials and linear shapes that accentuate function. Nevertheless, Gurlitt integrates interior design into the broader reflection on taste: even though the bulk of his Im Bürgerhause consists of a collection of thoughts on each segment of a modern home, he relates questions of style to literature and painting. Before asking what a stylish interior is, Gurlitt wonders whether the style of a poem is something eternal and human or something ephemeral, "measured to us and our time" (das uns und unserer Zeit Gemässe, Gurlitt, 1888, p 33).

Reflecting on the interior means debating our interiority, more precisely clarifying our understanding of the past, both its aesthetic values and our specific understanding of style, including the role that fashion plays. Reflecting on interior design is not just a question of arranging and designing furniture, choosing appropriate colours or adapting past building to new requirements; it is a question of building up a scenography for our subjective life, our values, emotions and thoughts. The modernist adaptation of forms to functions means precisely that the interiority of the modern subject has become an adaptable machine. A lot of contemporary interior design, especially in the context of retail, aims at the mechanisation of human interiority, its adaptation to a flat process of consumption, adjusting it to one function only: consume.

However, the correlation between interior design and interiority is immanent for reasons of representation. Theorists like Gaston Bachelard and novelists like Georges Perec were quite aware that the interior has always been a figure of consciousness in all its dimensions. Interiority is a space where all the trajectories of consciousness as intentional experience unfold, from awareness to remembrance and imagination. In this sense, the interior is a constitutive figure of consciousness, as Jean-Louis Chrétien has shown, from Augustine to Montaigne and beyond (Chrétien, 2014). In medieval times, closing the door of a room and falling back on oneself was an opportunity to encounter God in the cubiculum cordis, the so-called closed "room of the heart" (Chrétien, 2014, p 47). One could be on one's own but this condition facilitated prayers, reflections, meditations, etc. The interior was a closed room but interiority (the cubiculum cordis) was directed somewhere else. With Montaigne (On Solitude), being alone captures the modern condition of reflecting autonomously, alone with oneself. Even though Augustine wrote his Soliloquies in order to know himself, this self-knowledge constantly presupposes the presence of the Almighty. With the moderns, the interior of a room is a safe space of a monologue, with no necessary relation to any God (Chrétien, 2014, p 93). Nevertheless, interiority in all its forms-from the monk's cell (Guillaume de Saint-Thierry) to cultivating one's garden (Voltaire)-shapes both the secular and the religious consciousness.
Significant here is that this representation of the inner space affects the way we represent the world to ourselves. It is in this sense that interior design is significant: the interior is a figure of our subjectivity but this is only important because it signals how we think of the world outside of ourselves: Voltaire's garden suggests a reflective stance that delimits the complex world to limited, local and direct activities; Montaigne's closed room suggests that thinking the world necessitates this temporary seclusion. The pre-modern understanding of the interior as an openness towards divinity becomes in modernity a position that thinking takes towards the world. We could quote the usual examples and move from Xavier de Maistre's Voyage Around My Room (1794), which represents an entire world from the confines of a bedroom, to George Perec's interior as a seralisation of objects, movements and operations. Perec's significance becomes obvious when we read Species of Spaces (2008) together with An Attempt at Exhausting a Place in Paris (2010) and Penser/Classer (2003). This parallel reading proves that interiority, the inner life of the mind, becomes a way of perceiving the 'public interior' (to use Pimlott's notion) as sequences, classification and processes. With Perec, the interior is a model for representing the exterior world. In Thomas Bernhard's Old Masters (2010), a museum room with a Tintoretto painting and a settee facilitates an entire narrative improvisation and social commentary. The museum interior is here an opportunity to criticise modern society, its values and cultural choices. The interior opens up the protagonist's interiority, a space with own depth, imagination, directions and borders.

\section{From art history to theory}

Hence, the precisely delimited enquiry of the interior as interiority: the interior is analysed in order to deduce how the world as a horizon is represented, addressed and modified. The accompanying thematic collection approaches this subject from a systematic point of view, combining different positions, from the history of art and architecture to architectural theory and philosophy. The content can be divided into two thematic sections, the first concerning conceptual approaches of the interior as interiority, and the second discussing art historical approaches of the same topic. Regarding the first approach, Verschaffel's essay addresses the interior as a concept distinguished from a generic "outside"; interior design debates this dialectic and makes sense when the interior is thematised as a series of demarcations and transitions, from the original womb to the house (Verschaffel, 2017). The essay provides descriptions of the interior's constitutive elements: the floor (related to earth), the wall (related to the world) and the roof (related to heaven). A similar topological approach returns in Forino's intervention, a profound and original look into spatializing elements within the interior (the Renaissance studiolo, the bed, the window) that crystalize inherently human dimensions like attention and reflection (Forino, 2017). The notion of interno nell'interno tackles precisely the architectural potential that these "residual spaces" have. These elements represent subjectivity as an interiority where memory, reflection, mediation and introspection define its infinite propensity.

Consciousness is thus built on architectural principles and these tectonic figures return in the paper by Wambacq and van Tuinen (2017). The authors compare the anthropological philosophy of Peter Sloterdijk with the one signed Gilles Deleuze and Felix Guattari. Sloterdijk's images of interiors (from the bubble to the uterus) is contrasted to Deleuze and Guattari's reception of the Umwelt (Jakob von Uexüll) as an opening up of organisms towards the world. For Sloterdijk civilisation is a process that projects the protective sense of an interior onto an increasingly colonised and foreign exterior. The interior is a process that formats the unknown, rendering it familiar. For Deleuze and 
Guattari, organisms fold on each other, like the orchid and the wasp, one entity emulating a part of the other. Instead of borders that divide the interior and the exterior, the known and the unknown, Deleuze and Guattari propose an absolute exterior, imagined as a series of transitions between intervals that interact and fracture (spatial) identities. From intervals to a historically layered conception of the interior, Brooker advances the notion of interiorscape (Brooker, 2017). Referring to the work of Katsuhiro Miyamoto, Brooker observes the blend between old and new structures, an amalgamation that the adaptation of old buildings requires. An intermediate space set within existing fragile structures can generate a novel spatial context. The interiorscape is a design approach that combines structures in order to show the present as built between the layers of the past but also in order to represent history as a layered space.

In regard to the art historical approach, this collection introduces a case study of modernist interiors. Campens (2017) addresses the architecture of the Belgian architect Juliaan Lampens and raises a fundamental question concerning the relationship between the prescriptive ways of living that modernist interiors presuppose and their necessary adaptability to new conditions. Binstock (2017) is the Vermeer specialist and Vermeer is the interior painter par excellence. His essay addresses Vermeer's interiors as affective dimensions of interiority: melancholy, love, worry, attention and reflection are figured in these implicitly constructivist approach of the Dutch 17th century painter. The art of looking depends on the art of spatial arrangements and temporary states of mind are indistinguishable from an adaptable studio. Bauer's contribution addresses a common isotopy in modern literature, namely the common ground that emerges between characters and their surrounding environment (Bauer, 2017). Concentrating on Balzac's novel Colonel Chabert (2012), Bauer shows how the interior becomes a scenography for the experience of historical time: houses bear a physiognomy and in The Cabinet of Antiquities (1987) objects and people blend into a tableau. Shifting between media and ages, one can see how Vermeer's clear depictions contrasts with Balzac's grotesque vision of the human condition.

\section{The interior becomes a figure of interiority}

In conclusion, the interior coagulates architectonic space and turns into a readable place, a locally and temporally determinable dimension of meaning that generates specific movements, activities and roles. In this research context, the interior as interiority proposes a specific approach: instead of conceiving interior design strictly as the disposition of objects in space, the interior becomes a figure of interiority. The decorum of our lived space, its furniture, walls and roof, is significant because it is a representation of our subjectivity: how we live is a sign of how we think, feel and imagine the world. Relating the interior to interiority, interior design addresses a different challenge than that of comfortable spatial arrangements; it overcomes the reflection on interior space as a question of taste and decoration. The interior becomes an issue concerning representation: it is a model of our subjective life that in turn allows us to better understand the world we live in.

Received: 5 March 2018 Accepted: 6 March 2018

Published online: 27 March 2018

\section{Notes}

1 Ionescu V (ed) (2017) Interiorities: artistic, conceptual and historical reassessments of the interior (Article Collection). Palgrave Communications. https://www.nature.com/ collections/kzvpjcgckf

\section{References}

Balzac H (1987) La vieille fille, Le cabinet des antiques. Flammarion, Paris Balzac H (2012) Le Colonel Chabert. Librairie Générale Française, Paris Bauer D (2016) Beyond the frame. Case studies. ASP Publishers, Brussels Bauer D (2017) Interior spaces as traces in Balzac's La Comédie humaine. Palgrave Commun 3:17043. https://doi.org/10.1057/palcomms.2017.43

Benjamin W (1999) Arcades project. In: Eiland H, McLaughlin K (eds) The Belknap Press of Harvard University Press, Cambridge, Massachusetts

Bernhard T (2010) Old Masters. Penguin, London

Binstock B (2017) Interiors and interiority in Vermeer: empiricism, subjectivity, modernism. Palgrave Commun 3:17068. https://doi.org/10.1057/palcomms.2017.68

Brooker G (2017) The interiorscape: amalgams and composites. Palgrave Commun 3:17057. https://doi.org/10.1057/palcomms.2017.57

Campens A (2017) The sociological dimension of concrete interiors during the 1960s. Palgrave Commun 3:17035. https://doi.org/10.1057/palcomms.2017.35

Chrétien JL (2014) L'espace intérieur. Les éditions de Minuit, Paris

Corboz A (2001) Le territoire comme palimpseste et autres essais, présenté par Sébatien Marot. Éditions de l'imprimeur, Basançon

Forino I (2017) The interno nell'interno: some furnishing paradigms for an interior as interiority. Palgrave Commun 3:17022. https://doi.org/10.1057/ palcomms.2017.22

Fuss D (2004) The sense of an interior. Four writers and the rooms that shaped them. Routledge, New York

Gurlitt C (1888) Im Bürgerhause. Plaudereien über Kunst, Kunstgewerbe und Wohnungs-Ausstattung. Gilbersch'sche Königl. Hofverlagsbuchhandlung, Dresden

Hegewald J, Subrata M (2012) Re-use-The art and politics of integration and anxiet. Sage Publication, London

Hirth G (1886) Das deutsche Zimmer der Renaissance der Gothik und Renaissance, des Barock-, Rococo und Zopfstils, Dritte Stark Vermehrte Auflage. G. Hirth's Verlag, München

Hollis E (2009) The house of life and the memory palace. Some thoughts on the historiography of interiors. Interiors 1(2010):105-117

Kant I (2000) Critique of the power of judgment. In: Guyer P, Matthews E (eds). Cambridge University Press, Cambridge

Lane BM (2007) Housing and dwelling. Perspectives on modern domestic architecture. Routledge, London

Machado R (1976) Towards a theory of remodelling: old buildings as palimpsest. Prog Arch 11(1976):46-49

Massey A (1997) Interior design, history and development. In: Banham J (ed) Encyclopaedia of interior design. Routledge, London, pp 609-612

Perec G (2008) Species of Spaces and Other Pieces. Penguin Books, London

Perec G (2010) An Attempt at Exhausting a Place in Paris. Wakefield Press, Adelaide

Perec G (2003) Penser/Classer. Seuil, Paris

Pile J, Gura J (2014) A history of modern design. Wiley, Hoboken

Pimlott M (2016) The public interior as idea and project. Jap Sam Books, Heijningen

Sparke P (2008) The modern interior. Reaktion Books, London

Raizman D (2003) History of modern design, graphics and products since the industrial revolution. Laurence King, London

Rice C (2007) The emergence of the interior. Architecture, modernity, domesticity. Routledge, London

Rosner V (2005) Modernism and the architecture of private life. Columbia University Press, New York

Smyth G, Croft J (2006) Our house. The representation of domestic space in modern culture. Rodopi, Amsterdam

Taylor M, Preston J (2006) Intimus. Interior design theory reader. Wiley Academy, Hoboken

Thompson JA, Blossom NH (2015) The handbook of interior design. Wiley Blackwell, West Sussex

Trachtenberg M (2010) Building-in-time. From Giotto to Alberti and Modern Oblivion. Yale University Press, New Haven

Verschaffel B (2002) The meanings of domesticity. J Archit 7:287-296

Von Falke J (1866) Geschichte des modernen Geschmacks. Weigel, Leipzig

Weinthal L (2011) Toward a new interior. An anthology of interior design theory. Princeton Architectural Press, New York

Wambacq J, van Tuinen S (2017) Interiority in Sloterdijk and Deleuze. Palgrave Commun 3:17072. https://doi.org/10.1057/palcomms.2017.72

Woolf V (1924) Mr. Bennett and Mrs. Brown. The Hogarth Press, London

Verschaffel B (2017) The interior as architectural principle. Palgrave Commun 3:17038. https://doi.org/10.1057/palcomms.2017.38

\section{Additional information}

Competing interests: The author declares no competing financial interests.

Reprints and permission information is available online at http://www.nature.com/ reprints 
Publisher's note: Springer Nature remains neutral with regard to jurisdictional claims in published maps and institutional affiliations.

(c) (i) Open Access This article is licensed under a Creative Commons Attribution 4.0 International License, which permits use, sharing, adaptation, distribution and reproduction in any medium or format, as long as you give appropriate credit to the original author(s) and the source, provide a link to the Creative Commons license, and indicate if changes were made. The images or other third party material in this article are included in the article's Creative Commons license, unless indicated otherwise in a credit line to the material. If material is not included in the article's Creative Commons license and your intended use is not permitted by statutory regulation or exceeds the permitted use, you will need to obtain permission directly from the copyright holder. To view a copy of this license, visit http://creativecommons.org/ licenses/by/4.0/.

(c) The Author(s) 2018 